\title{
Evaluation of fetal condition in uncomplicated pregnancies at 40 weeks and beyond by calculation of amniotic fluid indexes and Doppler in the middle cerebral artery.
}

\author{
elvira semenova $^{1}$, Nikolai Rukhliada ${ }^{1}$, and Olga Klicenko ${ }^{2}$ \\ ${ }^{1}$ Saint Petersburg State Pediatric Medical University \\ ${ }^{2}$ Mechnikov North-Western State Medical University
}

January 8, 2021

\begin{abstract}
Objective. The aim of our data is to reveal the method of prognosis abnormal perinatal outcome, using combination US and Doppler results in uncomplicated pregnancies at 40 weeks and beyond. Design.1020 uncomplicated pregnant women at 40 weeks and beyond were examined 48 hours before delivery. We analyzed fetus's condition during labor and just after. Setting. According these dates all women were divided into 3 groups after amniotic index(AI)and pulsatility indices(PI) in the middle cerebral artery(MCA). Population.260 women were included in the study because they met the inclusion criteria. Methods.All women were divided into 3 groups (group 1 - PI $>0.835$, any value of AI, group 2-AI >85, PI [?] 0.835, group 3- AI [?] 85 and PI [?] 0.835).We analyzed fetus's condition during labor and just after delivery (Apgar score $<=7$ and $>7$ on the 1 st minute). Result. We've got trigger level for pulsatility index (PI) as 0.835 , if we had PI less than that threshold cases of emergency cesarean section increases in 2,12 times, if PI less than 0,835 in combination with Amniotic Index(AI) 85 and less in 5,28 times. If $\mathrm{PI}=<0,835$ risk of newborns having Apgar 7 and less increases in 1,18, but in combination with $\mathrm{AI}=<85$ in 4,72 times. Conclusion. In results we found out the following data: low PI in the MCA may be parameter which cans prognoses fetus distress. Combination of PI reduce with low AI increases its specific and can use in practical ways to avoid hypoxic brain damage during labor.
\end{abstract}

\section{Hosted file}

Evaluation of fetal condition in uncomplicated pregnancies at 40 weeks and beyond by calculation of AI available at https://authorea.com/users/376154/articles/503056-evaluation-of-fetalcondition-in-uncomplicated-pregnancies-at-40-weeks-and-beyond-by-calculation-ofamniotic-fluid-indexes-and-doppler-in-the-middle-cerebral-artery

\section{Hosted file}

figure 1.pdf available at https://authorea.com/users/376154/articles/503056-evaluation-offetal-condition-in-uncomplicated-pregnancies-at-40-weeks-and-beyond-by-calculation-ofamniotic-fluid-indexes-and-doppler-in-the-middle-cerebral-artery

\section{Hosted file}

figure 2.pdf available at https://authorea.com/users/376154/articles/503056-evaluation-offetal-condition-in-uncomplicated-pregnancies-at-40-weeks-and-beyond-by-calculation-ofamniotic-fluid-indexes-and-doppler-in-the-middle-cerebral-artery

\section{Hosted file}


figure 3.pdf available at https://authorea.com/users/376154/articles/503056-evaluation-offetal-condition-in-uncomplicated-pregnancies-at-40-weeks-and-beyond-by-calculation-ofamniotic-fluid-indexes-and-doppler-in-the-middle-cerebral-artery

\section{Hosted file}

figure 4.pdf available at https://authorea.com/users/376154/articles/503056-evaluation-offetal-condition-in-uncomplicated-pregnancies-at-40-weeks-and-beyond-by-calculation-ofamniotic-fluid-indexes-and-doppler-in-the-middle-cerebral-artery

\section{Hosted file}

figure 5.pdf available at https://authorea.com/users/376154/articles/503056-evaluation-offetal-condition-in-uncomplicated-pregnancies-at-40-weeks-and-beyond-by-calculation-ofamniotic-fluid-indexes-and-doppler-in-the-middle-cerebral-artery

\section{Hosted file}

figure 6.pdf available at https://authorea.com/users/376154/articles/503056-evaluation-offetal-condition-in-uncomplicated-pregnancies-at-40-weeks-and-beyond-by-calculation-ofamniotic-fluid-indexes-and-doppler-in-the-middle-cerebral-artery 